JURNAL GIZI DAN DIETETIK INDONESIA

Vol. 4, No. 2, Mei 2016: 105-111
Tersedia online pada: http://ejournal.almaata.ac.id/index.php/IJND

DOI : http://dx.doi.org/10.21927/ijnd.2016.4(2).105-111

\title{
Waktu pemberian makanan pendamping ASI (MP-ASI) berhubungan dengan kejadian stunting anak usia 6-23 bulan di Kecamatan Sedayu
}

Time of complementary feeding introduction was associated with stunting in children 6-23 months old in Sedayu, Bantul

Dwi Puji Khasanah ${ }^{1}$, Hamam Hadi ${ }^{1}$, Bunga Astria Paramashanti ${ }^{1}$

\begin{abstract}
Background: Stunting in children 6-23 months old was not directly realized and can be looked after they are 2 years old. Almost 18.08\% in District Bantul suffered from stunting. Stunting in children 6-23 months, may be correlated with the first time of complementary feeding introduction and inadequate intake of nutrients (energy and protein).

Objectives: To know the association between time of complementary feeding introduction, energy and protein intake with stunting in children 6-23 months old in Sedayu.

Methods: This was an observational study with cross sectional design. Research locations was in District of Sedayu, Bantul, Yogyakarta.The subject of study was children 6-23 months old in Sedayu. Samples were 190 children aged 6-23 months selected by using technique probability proportional to size (pps). The status of stunting in children was measured based on body length/age and used to analyze the risk of complementary feeding with stunting.

Results: The results of the analysis bivariat showed that early complementary feeding was significantly associated with stunting (OR=2.867, 95\% Cl:1.453-5.656). Intake of energy and proteins had no association with stunting $(p=0.005)$.

Conclusions: There were association between time of complementary feeding introduction with stunting. Intake of energy and protein were not risk factors of stunting in children aged 6-23 months in Sedayu Subdistrict, Bantul, Yogyakarta.
\end{abstract}

KEYWORDS: complementary feeding, intake of energy, intake of protein, stunting

\begin{abstract}
Latar belakang: Terjadinya stunting pada baduta seringkali tidak disadari, dan setelah dua tahun baru terlihat ternyata balita tersebut pendek. Sebesar 18,08\% balita di Kabupaten Bantul menderita stunting. Penyebab terjadinya stunting pada anak usia 6-23 bulan erat kaitannya dengan waktu pertama pemberian makanan pendamping ASI (MP-ASI) serta asupan zat gizi (energi dan protein) pada makanan yang kurang memadai.

Tujuan: Mengetahui hubungan antara waktu memulai pemberian serta jumlah asupan energi dan protein dari MP-ASI dengan kejadian stunting pada anak usia 6-23 bulan di Kecamatan Sedayu.

Metode: Jenis penelitian adalah observasional dengan desain studi cross sectional. Lokasi penelitian di Kecamatan Sedayu Kabupaten Bantul Yogyakarta. Subjek penelitian adalah anak usia 6-23 bulan di Kecamatan Sedayu. Besar sampel yang dibutuhkan adalah 190 anak usia 6-23 bulan. Pemilihan subjek penelitian menggunakan teknik probability proportional to size (PPS). Untuk mengetahui status stunting pada anak dilakukan pengukuran panjang badan menurut umur $(P B / U)$ dan digunakan analisis besarnya risiko pemberian MP-ASI terhadap kejadian stunting.
\end{abstract}

\footnotetext{
${ }_{1}$ Prodi S1 IImu Gizi Universitas Alma Ata Yogyakarta, Jl. Ringroad Barat Daya No 1, e-mail: pujikhasanah03@gmail.com
} 
Hasil: Hasil analisis bivariat menunjukan waktu pertama kali pemberian MP-ASI berhubungan signifikan dengan kejadian stunting (OR=2,867, 95\%Cl:1,453-5,656). Asupan energi dan protein tidak berhubungan dengan kejadian stunting ( $p>0,005)$.

Kesimpulan: Terdapat hubungan yang signifikan antara waktu pertama pemberian MP-ASI yang terlalu dini terhadap kejadian stunting. Asupan energi dan protein yang kurang tidak berhubungan dengan kejadian stunting pada anak usia 6-23 bulan di Kecamatan Sedayu, Bantul, Yogyakarta.

KATA KUNCI: pemberian MP-ASI, asupan energi, asupan protein, stunting

\section{PENDAHULUAN}

Lebih dari sepertiga anak berusia di bawah lima tahun di Indonesia tingginya berada di bawah rata-rata (1). Stunting adalah masalah kurang gizi kronis yang disebabkan oleh asupan gizi yang kurang dalam waktu cukup lama akibat pemberian makanan yang tidak sesuai dengan kebutuhan gizi (2).

Masalah gizi yang banyak terjadi di Indonesia sebagai negara berkembang saat ini yaitu gizi kurang, pendek, dan kurus. Secara nasional, berdasarkan riset kesehatan dasar 2013, prevalensi stunting nasional mencapai $37,2 \%$ yang terdiri dari $18,0 \%$ anak sangat pendek dan $19,2 \%$ anak pendek, meningkat dari tahun 2010 (35,6\%) dan 2007 (36,8\%). Prevalensi balita stunting di Provinsi Daerah Istimewa Yogyakarta (DIY) lebih rendah daripada angka nasional yaitu $28,5 \%$ (3). Senada dengan data ini, berdasarkan Laporan Tahunan Dinas Kesehatan Kabupaten Bantul Tahun 2012 diperoleh data sebesar $18,08 \%$ balita di Kabupaten Bantul menderita stunting (4).

Salah satu permasalahan dalam pemberian makanan pada bayi adalah terhentinya pemberian air susu ibu (ASI) dan pemberian MP-ASI yang tidak cukup (5). WHO merekomendasikan pemberian ASI eksklusif 6 bulan pertama kehidupan dan dilanjutkan dengan pengenalan MP-ASI dengan terus memberikan ASI sampai usia 2 tahun (6). Menurut penelitian Teshome, anak yang diberi MP-ASI terlalu dini ( $<4$ bulan) berisiko menderita kejadian stunting (7).

Kecamatan Sedayu merupakan salah satu kecamatan di Kabupaten Bantul yang dilalui jalan antarkota dan kabupaten. Keadaan ini membuat adanya perubahan dan perbedaan mobilitas penduduk, sosial ekonomi, pola konsumsi, ketersediaan pangan, dan gaya hidup masyarakat di Kecamatan Sedayu (8). Prevalensi stunting balita di Kecamatan Sedayu sebesar $16,93 \%$, dan merupakan tertinggi ke-2 setelah Kecamatan Bambanglipuro di Kabupaten Bantul (4). Tujuan dari penelitian ini adalah untuk mengetahui hubungan antara praktik pemberian MP-ASI dengan kejadian stunting anak usia 6-23 bulan di Kecamatan Sedayu Yogyakarta.

\section{BAHAN DAN METODE}

Penelitian ini menggunakan rancangan studi cross sectional (pontong lintang) merupakan penelitian deskriptif. Pada penelitian tersebut, subjek penelitian diamati, diukur, diminta jawabannya satu kali saja (9). Jenis penelitian ini adalah observasional analitik dengan design cross sectional yang dilaksanakan pada bulan Maret sampai dengan April tahun 2016 di Kecamatan Sedayu Kabupaten Bantul dan pengujian sampel jajanan dilakukan di Laboratorium Universitas Alma Ata Yogyakarta. Metode pengambilan sampel dengan probability proportional to size (PPS) yang terdiri dari 10 klaster posyandu. Berdasarkan perhitungan diperoleh besar sampel minimal adalah 185. Data yang diambil di lapangan sebesar 190 sampel.

Variabel bebas adalah waktu pertama pemberian MP-ASI. Usia pemberian MP-ASI pertama adalah waktu pengenalan MP-ASI pertama di masa kehidupan baduta yang dinyatakan dalam bulan umur kelahiran. Interval usia 6 bulan adalah 6 bulan sampai dengan 6 bulan 29 hari (10), dan asupan energi dan protein, data asupan energi adalah total asupan energi dan protein baduta yang didapatkan dari asupan makan dalam satu hari dengan metode semi food frequency. Variabel terikat adalah kejadian stunting pada anak usia 
6-23 bulan. Analisis univariat dilakukan dengan menggunakan tabel frekuensi dan analisis bivariat dengan uji chi-square.

\section{HASIL}

\section{Karakteristik responden}

Berdasarkan Tabel 1 menunjukkan bahwa karakteristik responden berdasarkan usia ibu untuk persentase terbanyak usia $20-30$ tahun $(64,2 \%)$ dan sisanya berumur 31-40 tahun. Karakteristik ibu responden berdasarkan tingkat pendidikan sebanyak $87 \mathrm{ibu}(45,8 \%)$ berpendidikan terakhir setingkat SMA dan paling sedikit yang berpendidikan tamat SD yaitu sebanyak 12 orang (6,3\%). Sebagian besar ibu $(55,8 \%)$ tidak bekerja. Karakteristik responden berdasarkan pekerjaan suami sebesar $90,5 \%$ suami (96 orang) bekerja sebagai wiraswasta. Jumlah baduta terbesar usia 12-23 bulan yaitu 153 orang (70\%). Untuk jumlah baduta terbanyak dengan jenis kelamin laki-laki sebanyak 113 orang (59,5\%). Karakteristik responden berdasarkan kejadian stunting persentase kelompok anak yang mengalami stunting sebanyak 58 responden (30,5\%) dan yang paling banyak anak tidak mengalami stunting yaitu sebesar 132 anak $(69,5 \%)$.

\section{Hubungan antara waktu pertama kali pemberian MP-ASI dengan kejadian stunting}

Pada Tabel 2 tampak hubungan bermakna $(p=0,002)$ antara waktu pertama kali pemberian MP-ASI dengan status gizi anak usia 6-23 bulan menggunakan indeks panjang badan terhadap usia. Hal ini berarti waktu pertama kali pemberian MP-ASI mempengaruhi kejadian stunting. Waktu pertama kali pemberian MP-ASI memiliki pengaruh 2,8 kali lebih besar terhadap kejadian stunting.
Tabel 1. Karakteristik keluarga responden

\begin{tabular}{|c|c|c|c|}
\hline Karakteristik Keluarga & $\begin{array}{c}\text { Jumlah } \\
\text { (n) }\end{array}$ & $\begin{array}{c}\text { Persentase } \\
(\%)\end{array}$ & $\begin{array}{c}\text { Total } \\
(\%)\end{array}$ \\
\hline \multicolumn{4}{|l|}{ Umur ibu } \\
\hline $20-30$ tahun & 122 & 64,2 & 100 \\
\hline $31-40$ tahun & 68 & 35,8 & \\
\hline \multicolumn{4}{|l|}{ Pendidikan ibu } \\
\hline SD & 12 & 6,3 & 100 \\
\hline SMP & 53 & 27,9 & \\
\hline SMA & 87 & 45,8 & \\
\hline Perguruan tinggi & 38 & 20,0 & \\
\hline \multicolumn{4}{|l|}{ Pekerjaan ibu } \\
\hline Tidak bekerja/IRT & 106 & 55,8 & 100 \\
\hline $\begin{array}{l}\text { Buruh tani/industri/ } \\
\text { petani }\end{array}$ & 7 & 3,7 & \\
\hline $\begin{array}{l}\text { Pegawai swasta/ } \\
\text { PNS }\end{array}$ & 56 & 29,5 & \\
\hline $\begin{array}{l}\text { Wiraswasta/dagang/ } \\
\text { pengusaha }\end{array}$ & 21 & 11,1 & \\
\hline \multicolumn{4}{|l|}{ Pekerjaan suami } \\
\hline Tidak bekerja & 1 & 0,5 & 100 \\
\hline $\begin{array}{l}\text { Buruh tani/industri/ } \\
\text { petani }\end{array}$ & 59 & 31,1 & \\
\hline $\begin{array}{l}\text { Pegawai swasta/ } \\
\text { PNS }\end{array}$ & 96 & 50,5 & \\
\hline $\begin{array}{l}\text { Wiraswasta/dagang/ } \\
\text { pengusaha }\end{array}$ & 34 & 17,9 & \\
\hline \multicolumn{4}{|l|}{ Usia anak } \\
\hline $6-11$ bulan & 57 & 30,0 & 100 \\
\hline 12 - 23 bulan & 153 & 70,0 & \\
\hline \multicolumn{4}{|l|}{ Jenis kelamin } \\
\hline Laki-laki & 113 & 59,5 & 100 \\
\hline Perempuan & 77 & 40,5 & \\
\hline
\end{tabular}

Hubungan antara asupan energi dengan status gizi tinggi badan menurut umur pada anak usia 6-23 bulan di Kecamatan Sedayu

Pada Tabel 3 tampak bahwa tidak ada hubungan bermakna $(p=0,072)$ antara asupan energi dengan status gizi anak usia 6 - 23 bulan

Tabel 2. Distribusi frekuensi responden berdasarkan waktu pertama kali pemberian MP-ASI menurut status gizi indeks panjang badan terhadap usia

\begin{tabular}{|c|c|c|c|c|c|c|c|c|}
\hline \multirow{3}{*}{$\begin{array}{l}\text { Waktu pertama pemberian } \\
\text { MP-ASI }\end{array}$} & \multicolumn{6}{|c|}{ Kejadian stunting } & \multirow{3}{*}{$\begin{array}{c}\text { OR } \\
(95 \% \mathrm{Cl})\end{array}$} & \multirow{3}{*}{$\mathbf{p}$} \\
\hline & \multicolumn{2}{|c|}{ Stunting } & \multicolumn{2}{|c|}{ Normal } & \multicolumn{2}{|c|}{ Total } & & \\
\hline & $\mathbf{n}$ & $\%$ & $\mathbf{n}$ & $\%$ & $\mathbf{n}$ & $\%$ & & \\
\hline Tidak sesuai ( $<6$ atau $>6$ bulan) & 43 & 39,4 & 66 & 60,6 & 109 & 100 & $\begin{array}{c}2,867 \\
(1,453-5,656)\end{array}$ & $0,002^{*}$ \\
\hline Sesuai (6 bulan) & 15 & 18,5 & 43 & 81,5 & 81 & 100 & & \\
\hline Jumlah & 58 & 30,5 & 132 & 69,5 & 190 & 100 & & \\
\hline
\end{tabular}

* Signifikan $(p<0,05)$ 
Tabel 3. Hubungan antara asupan energi dengan status gizi anak usia 6 - 23 bulan indeks panjang badan menurut umur

\begin{tabular}{|c|c|c|c|c|c|c|c|c|}
\hline \multirow{3}{*}{ Asupan energi } & \multicolumn{6}{|c|}{ Kejadian stunting } & \multirow{3}{*}{$\begin{array}{c}\text { OR } \\
(95 \% \mathrm{Cl})\end{array}$} & \multirow{3}{*}{$\mathbf{p}$} \\
\hline & \multicolumn{2}{|c|}{ Stunting } & \multicolumn{2}{|c|}{ Normal } & \multicolumn{2}{|c|}{ Total } & & \\
\hline & $\mathbf{n}$ & $\%$ & $\mathbf{n}$ & $\%$ & $\mathbf{n}$ & $\%$ & & \\
\hline Rendah $(<70 \%$ AKG) & 31 & 37,3 & 52 & 62,7 & 83 & 100 & $\begin{array}{c}1,766 \\
(0,947-3,293)\end{array}$ & 0,072 \\
\hline Cukup ( $\geq 70 \%$ AKG) & 27 & 25,2 & 80 & 74,8 & 107 & 100 & & \\
\hline Jumlah & 58 & 30,5 & 132 & 69,5 & 190 & 100 & & \\
\hline
\end{tabular}

indeks panjang badan terhadap usia, artinya asupan energi tidak mempengaruhi kejadian stunting.

\section{Hubungan antara asupan protein dengan status gizi tinggi badan menurut umur pada anak usia 6 - 23 bulan di Kecamatan Sedayu}

Pada Tabel 4 tampak bahwa tidak ada hubungan bermakna $(p=0,735)$ antara asupan protein dengan status gizi anak usia 6 - 23 bulan indeks panjang badan terhadap usia. Hal ini berarti asupan protein tidak mempengaruhi kejadian stunting.

\section{BAHASAN}

\section{Waktu memulai pemberian MP-ASI}

Waktu memulai pemberian MP-ASI anak usia 6-23 bulan dibagi menjadi 2 kategori, yaitu sesuai dan tidak sesuai. Kategori waktu pemberian MPASI yang sesuai adalah usia 6 bulan 29 hari dan kategori waktu pemberian MP-ASI tidak sesuai adalah usia $<6$ atau $>6$ bulan. Anak usia $6-23$ bulan di Kecamatan Sedayu yang menerima MP-ASI pertama pada usia 6 bulan sebesar $43,2 \%$ dan untuk MP-ASI sebelum 6 bulan dan lebih dari 6 bulan sebesar $56,8 \%$.

Berdasarkan Tabel 4 diperoleh hasil bahwa ada hubungan antara waktu memulai pemberian
MP-ASI dengan status gizi anak usia 6-23 bulan berdasarkan panjang badan menurut umur (PB/U) (OR=2,867, 95\% Cl:1,453-5,656). Anak yang mendapatkan MP-ASI yang tidak sesuai dengan waktu memulai pemberian MP-ASI memiliki risiko 2,8 kali untuk menjadi stunting (z score <-2). Hal ini berarti waktu memulai pemberian MP-ASI berhubungan secara signifikan dengan kejadian stunting. Penelitian ini sejalan dengan penelitian yang dilakukan di Jember tentang faktor-faktor yang mempengaruhi kejadian stunting pada anak balita di wilayah pedesaan dan perkotaan. Hasil penelitian tersebut membuktikan bahwa praktik pemberian MP-ASI pada anak balita merupakan salah satu faktor yang mempengaruhi terjadinya stunting pada anak balita yang berada di daerah pedesaan dan perkotaan (11). Penelitian ini sesuai dengan Departemen Kesehatan (Depkes) yang menyatakan bahwa gangguan pertumbuhan pada awal masa kehidupan bayi antara lain disebabkan oleh kekurangan gizi sejak bayi, pemberian MP-ASI terlalu dini atau terlalu lambat, MP-ASI tidak cukup gizinya sesuai kebutuhan bayi atau kurang baiknya pola pemberiannya menurut usia, dan perawatan bayi yang kurang memadai (12). Anak balita yang diberikan ASI eksklusif dan MP-ASI sesuai dengan dengan kebutuhannya dapat mengurangi risiko terjadinya stunting. Hal ini karena pada usia 0-6

Tabel 4. Hubungan antara asupan protein dengan status gizi anak usia 6 - 23 bulan indeks panjang badan menurut umur

\begin{tabular}{|c|c|c|c|c|c|c|c|c|}
\hline \multirow{3}{*}{ Asupan protein } & \multicolumn{6}{|c|}{ Kejadian stunting } & \multirow{3}{*}{$\begin{array}{c}\text { OR } \\
(95 \% \mathrm{Cl})\end{array}$} & \multirow{3}{*}{$\mathbf{p}$} \\
\hline & \multicolumn{2}{|c|}{ Stunting } & \multicolumn{2}{|c|}{ Normal } & \multicolumn{2}{|c|}{ Total } & & \\
\hline & $\mathbf{n}$ & $\%$ & $\mathbf{n}$ & $\%$ & $\mathbf{n}$ & $\%$ & & \\
\hline Rendah (< $80 \%$ AKG) & 4 & 26,7 & 11 & 73,3 & 15 & 100 & $\begin{array}{c}0,815 \\
(0,248-2,674)\end{array}$ & 0,735 \\
\hline Cukup ( $\geq 80$ \% AKG) & 54 & 30,9 & 121 & 69,1 & 175 & 100 & & \\
\hline Jumlah & 58 & 30,5 & 132 & 69,5 & 190 & 100 & & \\
\hline
\end{tabular}


bulan ibu balita yang memberikan ASI eksklusif dapat membentuk imunitas atau kekebalan tubuh anak balita sehingga dapat terhindar dari penyakit infeksi. Setelah itu, pada usia 6 bulan anak balita diberikan MP-ASI dalam jumlah dan frekuensi yang cukup sehingga anak balita terpenuhi kebutuhan zat gizinya yang dapat mengurangi risiko terjadinya stunting.

\section{Asupan energi anak usia $\mathbf{6}$ - 23 bulan}

Asupan energi anak usia 6-23 bulan dibagi menjadi 2 kategori, yaitu rendah dan cukup. Kategori asupan energi rendah apabila $<70 \%$ AKG dan kategori asupan cukup apabila $\geq 70 \%$ AKG. Asupan energi anak usia 6-23 bulan di Kecamatan Sedayu sebagian besar cukup, yaitu sebanyak $56,3 \%$, sisanya lagi sebesar $43,7 \%$ merupakan anak dengan asupan energi yang rendah.

Dari hasil uji analisis chi-square menunjukkan bahwa tidak terdapat hubungan yang signifikan antara riwayat asupan energi dengan kejadian stunting $(p>0,05)$ seperti terlihat pada Tabel $4(p=0,072)$. Diduga terdapat penyebab lain anak kekurangan zat gizi mikro seperti vitamin A dan zink. Asam retinoat yang merupakan salah satu bentuk vitamin A pada hormon yang mengontrol pertumbuhan, khususnya pertumbuhan jaringan skeletal (13). Menurut Cunane, zink mempengaruhi aktivitas beberapa hormon seperti human growth hormone (hormon pertumbuhan manusia). Pada anak-anak yang mengalami defisiensi vitamin $\mathrm{A}$ dan zink berpengaruh terhadap proses pertumbuhan linier (14).

Hasil penelitian ini sejalan dengan penelitian di Aceh tentang faktor risiko kejadian stunting pada baduta. Hasil penelitian tersebut menunjukkan bahwa anak dengan tingkat kecukupan energi yang rendah memiliki risiko sebesar 3,09 kali untuk menjadi stunting dibandingkan dengan anak yang memiliki tingkat kecukupan energi baik (15). Begitu pula dengan penelitian terdahulu yang dilakukan di Kecamatan Sedayu diperoleh hasil riwayat asupan energi dan protein yang kurang bukan merupakan faktor risisko stunting pada baduta. Hasil penelitian ini tidak sama dengan penelitian sebelumnya yang menyatakan ada hubungan signifikan antara asupan energi dengan stunting pada anak 13-36 bulan di Wilayah Kerja Puskesmas Tuminting Kota Manado (16). Perbedaan hasil hubungan antara asupan energi baduta dengan kejadian stunting pada penelitian ini bisa terjadi dikarenakan faktor lain seperti adanya konsumsi ASI yang tidak masuk dalam perhitungan total asupan energi dan juga riwayat penyakit infeksi.

\section{Asupan protein anak usia 6 - 23 bulan}

Asupan protein anak usia 6-23 bulan dibagi menjadi 2 kategori, yaitu rendah dan cukup. Kategori asupan protein rendah apabila $<80 \%$ AKG dan kategori asupan cukup apabila $\geq 80 \%$ AKG. Asupan protein anak usia 6-23 bulan di Kecamatan Sedayu sebagian besar cukup, yaitu sebanyak $92,1 \%$, sisanya lagi $7,9 \%$ adalah anak dengan asupan protein yang rendah (17).

Dari hasil uji analisis chi-square diperoleh nilai $p=0,072$ yang berarti tidak ada hubungan antara asupan protein dengan status gizi anak usia 6-23 bulan indeks panjang badan terhadap usia. Penelitian ini sejalan dengan penelitian terdahulu yang dilakukan di Kecamatan Sedayu bahwa tidak terdapat hubungan yang signifikan antara asupan protein dengan kejadian stunting $(p=0,04)$. Hal ini dapat disebabkan oleh beberapa hal seperti balita belum diberikan lauk hewani ataupun nabati, frekunsi pemberian makan yang kurang dan komposisi menu yang tidak tepat.

Penelitian ini tidak sejalan dengan penelitian yang dilakukan di Jember yang mendapatkan bahwa tingkat kecukupan protein di daerah pedesaan berhubungan dengan kejadian stunting pada anak balita (11). Hal tersebut disebabkan asupan zat gizi yang tidak adekuat, terutama dari protein berhubungan dengan masalah gangguan pertumbuhan fisik pada anak balita. Perbedaan hasil hubungan antara asupan protein balita dengan kejadian stunting pada penelitian ini bisa terjadi karena faktor lain seperti adanya penyakit infeksi atau penyakit penyerta yang dapat menghambat dan menggangu proses penyerapan protein. 


\section{KESIMPULAN DAN SARAN}

Berdasarkan hasil penelitian di Kecamatan Sedayu Kabupaten Bantul dapat diambil kesimpulan bahwa riwayat waktu memulai pemberian MP-ASI berhubungan secara signifikan dengan kejadian stunting (OR=2,867, 95\% Cl:1,453-5,656) dan memiliki resiko 2,8 kali menjadi stunting pada anak usia 6-23 bulan di Kecamatan Sedayu. Riwayat asupan energi dan protein yang kurang tidak berhubungan signifikan dengan kejadian stuntingpada anak usia 6 - 23 bulan di Kecamatan Sedayu.

Saran bagi petugas kesehatan agar dapat mengoptimalkan perannya dalam melakukan pelayanan gizi berupa edukasi gizi terhadap wanita pasangan usia subur (PUS) agar dapat mempersiapkan diri saat prenatal maupun neonatal yang pada akhirnya akan mengurangi risiko kejadian stunting. Edukasi kesehatan untuk semua wanita usia subur (WUS) agar di masa depan dapat lebih memahami mengenai pentingnya menjaga ststus gizi pada masa sebelum/masa remaja sampai kehamilan agar melahirkan bayi yang sehat. Saran untuk penelitian selanjutnya yaitu untuk mengetahui kecukupan asupan energi dan protein anak usia 6-23 bulan sebaiknya menghitung kandungan energi dan protein baik dari makanan yang dikonsumsi dan ditambah dari ASI. Selain itu, perlu pula ditambahkan penelitian mengenai hubungan antara asupan zat gizi mikro dengan stunting.

\section{RUJUKAN}

1. Departemen Kesehatan RI. Umur sama tinggi badan berbeda [Internet]. 2014 [cited 2015 Nov 20]. Available from: http://www.gizikia. depkes.go.id/terbitan/umur-samatinggi-badan berbeda/?print=pdf

2. Millenium Challenge Account-Indonesia. Stunting dan masa depan Indonesia [Internet]. Jakarta; 2014. Available from: http://mcaindonesia.go.id/wp-content/uploads/2015/01/ Backgrounder-Stunting-ID.pdf

3. Badan Penelitian dan Pengembangan Kesehatan Republik Indonesia. Riset kesehatan dasar 2013. Jakarta: Badan Penelitian dan Pengembangan Kesehatan RI; 2013.

4. Dinas Kesehatan Kabupaten Bantul. Profil kesehatan Kabupaten Bantul. Bantul: Dinas Kesehatan Kabupaten Bantul; 2012.

5. Departemen Kesehatan RI. Pola makan pendamping air susu ibu (MP-ASI). Jakarta: Departemen Kesehatan RI; 2000.

6. WHO. WHO / UNICEF joint monitoring programme (JMP) for water supply and sanitation [Internet]. 2010 [cited 2015 Apr 19]. Available from: http://www.wssinfo.org/

7. Teshome B, Makau W, Getahun Z, Taye G. Magnitude and determinants of stunting in children under-five years of age in food surplus of Ethiopia: the case of West Gojam Zone. Ethiop J Heal Dev. 2009;23(2):98-106.

8. Adriani M, Wirjatmadi B. Pengantar gizi masyarakat. Jakarta: Kencana Prenada Media Group; 2012.

9. Wibowo A. Metodologi penelitian praktis bidang kesehatan. Jakarta: Rajawali Pers; 2014.

10. Kementerian Kesehatan Republik Indonesia. Petunjuk pelaksanaan surveilans gizi. Jakarta: Kementerian Kesehatan RI; 2012.

11. Aridiyah F, Rohmawati N, Ririanty M. Faktorfaktor yang mempengaruhi kejadian stunting pada anak balita di wilayah pedesaan dan perkotaan. J Pustaka Kesehat. 2015;3(1):16370.

12. Hendra A, Miko A, Hadi A. Kajian stunting pada anak balita ditinjau dari pemberian ASI eksklusif, MP-ASI, status imunisasi dan karakteristik keluarga di Kota Banda Aceh. JKIN. 2010;6:169-84.

13. Adriani et al. Gizi dan kesehatan balita. Jakarta: Kencana Prenada Media Group; 2014.

14. Adriani M. Pengaruh seng pada suplementasi vitamin A dosis tinggi terhadap status infeksi dan pertumbuhan linier balita. Surabaya: Universitas Airlangga; 2009.

15. Hana S. Faktor risiko kejadian stunting pada anak usia 12-36 bulan di Kecamatan Pati Kabupaten Pati. Universitas Diponegoro; 2012. 
16. Tangkudung G. Hubungan antara asupan energi dengan kejadian stunting pada anak usia 13-36 bulan di Wilayah kerja Puskesmas Tuminting Kota Manado. Universitas Sam Ratulangi; 2014.
17. Wanda L, Ani M, Rahfiludin M. Faktor risiko stunting pada anakumur 6-24 bulan di Kecamatan Penanggalan kota SubulussalamProvinsi Aceh. J Gizi Indones. 2014;3(1):37-45. 